\title{
Regulation of the Mouse Medial Prefrontal Cortical Synapses by Endogenous Estradiol
}

\author{
Christopher Galvin' and Ipe Ninan*,I \\ 'Department of Psychiatry, New York University Langone Medical Center, New York, NY, USA
}

Recent studies suggest that low endogenous estradiol might be a susceptibility factor for anxiety and trauma-related disorders in women. Consistently, fear extinction, a form of inhibitory learning critical for the management of anxiety symptoms, is positively correlated with endogenous estradiol levels. To understand the synaptic basis of the effect of endogenous estradiol on fear extinction, we studied glutamatergic transmission and plasticity in the infralimbic medial prefrontal cortex (IL-mPFC), a brain region crucial for the regulation of fear extinction. Diestrus mice (low estradiol) exhibited a higher basal glutamatergic transmission compared with proestrus mice (high estradiol). Synaptic plasticity was also regulated by endogenous estradiol, which favored synaptic potentiation in a GluN2B-dependent manner. Activation of estrogen receptor $\beta(E R \beta)$ but not ER $\alpha$ rescued synaptic potentiation in diestrus mice by enhancing GluN2Bmediated NMDA receptor transmission. Our results suggest that both endogenous estradiol and ER $\beta$ activation facilitate the ability of the IL-mPFC synapses to undergo potentiation, a mechanism necessary for the regulation of fear extinction.

Neuropsychopharmacology (2014) 39, 2086-2094; doi:I0.1038/npp.20I4.56; published online 2 April 2014

\section{INTRODUCTION}

The incidence, severity and duration of trauma-related disorders, and anxiety symptoms are significantly higher in women (Holbrook et al, 2002). Despite the emergence of this gender difference during puberty, the trauma- and anxiety-related symptoms are negatively correlated with the endogenous estradiol levels (Angold et al, 1998; Hankin and Abramson, 1999; Lebron-Milad and Milad, 2012). Congruent with an increased vulnerability to affective disorders during periods of low endogenous estradiol such as menopause, postpartum and following oophorectomy (Altshuler et al, 1998; Harsh et al, 2009; Parker et al, 2009; Schmidt and Rubinow, 2009; Schnatz et al, 2010), an impairment in fear extinction, an inhibitory learning process that attenuates anxiety symptoms, has been associated with low endogenous estradiol (Davis, 2011; Milad et al, 2010). Although an estradiol-based approach might be beneficial in the management of anxiety symptoms, its multifaceted effects are a limitation for therapeutic utilization (Hall et al, 2001). Therefore, an in-depth understanding of the downstream mechanism by which estradiol modulates the neural circuitry pertinent to the regulation of fear behavior is necessary. The infralimbic medial prefrontal cortex (IL-mPFC) is believed to play an important role in the regulation of fear extinction (Quirk et al, 2000). It has been suggested that an enhanced glutamatergic input from the IL-mPFC activates amygdala

*Correspondence: Dr I Ninan, Department of Psychiatry, NYU School of Medicine, 540 IAve, New York, NY 10116, USA. Tel: + I 347 535 07/0, Fax: + I 212263 0723, E-mail: Ipe.Ninan@nyumc.org Received II September 2013; revised 28 February 2014; accepted 4 March 2014; accepted article preview online 10 March 2014 neurons particularly the GABAergic neurons in the intercalated cell masses and suppresses the centromedial amygdala output and fear response (Ninan, 2014; Pare et al, 2004). Consistently, the IL-mPFC glutamatergic synapses undergo potentiation during fear extinction (Pattwell et al, 2012b; Sepulveda-Orengo et al, 2013). To understand whether endogenous estradiol modulates the IL-mPFC synapses, we studied glutamatergic synaptic transmission and plasticity in the IL-mPFC layer 5 pyramidal neurons, the major projection neurons (Gabbott et al, 2005), from proestrus (high estradiol) and diestrus (low estradiol) mice (Spencer et al, 2010). Our studies revealed an estrous cycle-dependent modulation of the IL-mPFC glutamatergic synapses. Consistent with the high expression of estrogen receptor- $\beta(\operatorname{ER} \beta)$ in cortical areas including the mPFC and the beneficial effects of ER $\beta$ activation on anxiety behaviors and fear extinction (Kritzer, 2002; Milner et al, 2010; Oyola et al, 2012; Shughrue et al, 1997; Walf et al, 2008; Zeidan et al, 2011), $\operatorname{ER} \beta$ agonist restored the ability of the IL-mPFC glutamatergic synapses to undergo potentiation in diestrus mice.

\section{MATERIALS AND METHODS}

\section{Animals}

All experiments were approved by the Institutional Animal Care and Use Committee of the New York University School of Medicine. Three- to five-month-old C57/BL6 mice were maintained on a 12:12 light/dark cycle. Estrous cycle stage was determined by vaginal smear cytology between 0900 and 1100 hours. Hema 3 Stat Pack (Fisher Scientific) was used for processing the samples, and phases of estrous cycle were determined based on the presence of nucleated 
epithelial cells in proestrus, cornified epithelial cells in estrus, leukocytes, cornified epithelial cells, few nucleated epithelial cells, and cell debris in metestrus, and elevated presence of leukocytes and mucus and few nucleated epithelial cells in diestrus (Byers et al, 2012) (Figure 1a). Mice were selected for experiments following 8-10 days of regular estrous cycling. Ovariectomy was performed under ketamine/xylazine anesthesia. Ovaries were removed after making incisions of $5 \mathrm{~mm}$ on either sides about $10 \mathrm{~mm}$ from the midline (Strom et al, 2012). A control group was subjected to sham surgeries in which the ovaries were exteriorized but remained intact. Brain slices were prepared from ovariectomized and sham mice 10-14 days after the surgery.

\section{Electrophysiology}

Mouse brains were removed between 1000 and 1200 hours following intracardial perfusion with ice-cold artificial cerebrospinal fluid (ACSF) containing $\mathrm{NaCl}(118 \mathrm{mM})$, glucose $(10 \mathrm{mM}), \mathrm{KCl}(2.5 \mathrm{mM}), \mathrm{NaH}_{2} \mathrm{PO}_{4}$ (1 mM), $\mathrm{CaCl}_{2}$
(1 mM) and $\mathrm{MgSO}_{4}(2 \mathrm{mM})$ bubbled with $95 \% \mathrm{O}_{2} / 5 \% \mathrm{CO}_{2}$ (325 mOsm, pH 7.4) under pentobarbital anesthesia. mPFC slices $(300 \mu \mathrm{m})$ were prepared and allowed to recover for at least $1 \mathrm{~h}$ at room temperature before transferring to a recording chamber perfused with aforementioned ACSF $\left(32{ }^{\circ} \mathrm{C}\right)$ containing $2 \mathrm{mM} \mathrm{CaCl}{ }_{2}$. Spontaneous excitatory post-synaptic currents (sEPSCs), excitatory post-synaptic currents (EPSCs), and NMDA EPSCs were evoked in the IL-mPFC layer 5 pyramidal neurons using an electrode solution consisted of $\mathrm{CsCl}(145 \mathrm{mM})$, HEPES $(10 \mathrm{mM})$, EGTA (0.5 mM), QX-314 (5 mM), GTP (0.2 mM), and MgATP (5 mM) (osmolarity 290 mOsm, pH 7.4) (Pattwell et al, 2012a; Pattwell et al, 2012b). NMDA EPSC decay time constant and amplitude were assessed before and after the perfusion of ifenprodil $(10 \mu \mathrm{M})$ for $15 \mathrm{~min}$. NMDA miniature excitatory post-synaptic currents (mEPSCs) were recorded at $-50 \mathrm{mV}$ in the presence of bicuculline $(10 \mu \mathrm{M})$, NBQX $(10 \mu \mathrm{M})$, glycine $(10 \mu \mathrm{M})$, strychnine $(1 \mu \mathrm{M})$, and tetrodotoxin $(1 \mu \mathrm{M})$ and in the absence of magnesium. To test the role of pre-synaptic mechanism, we studied paired pulse facilitation
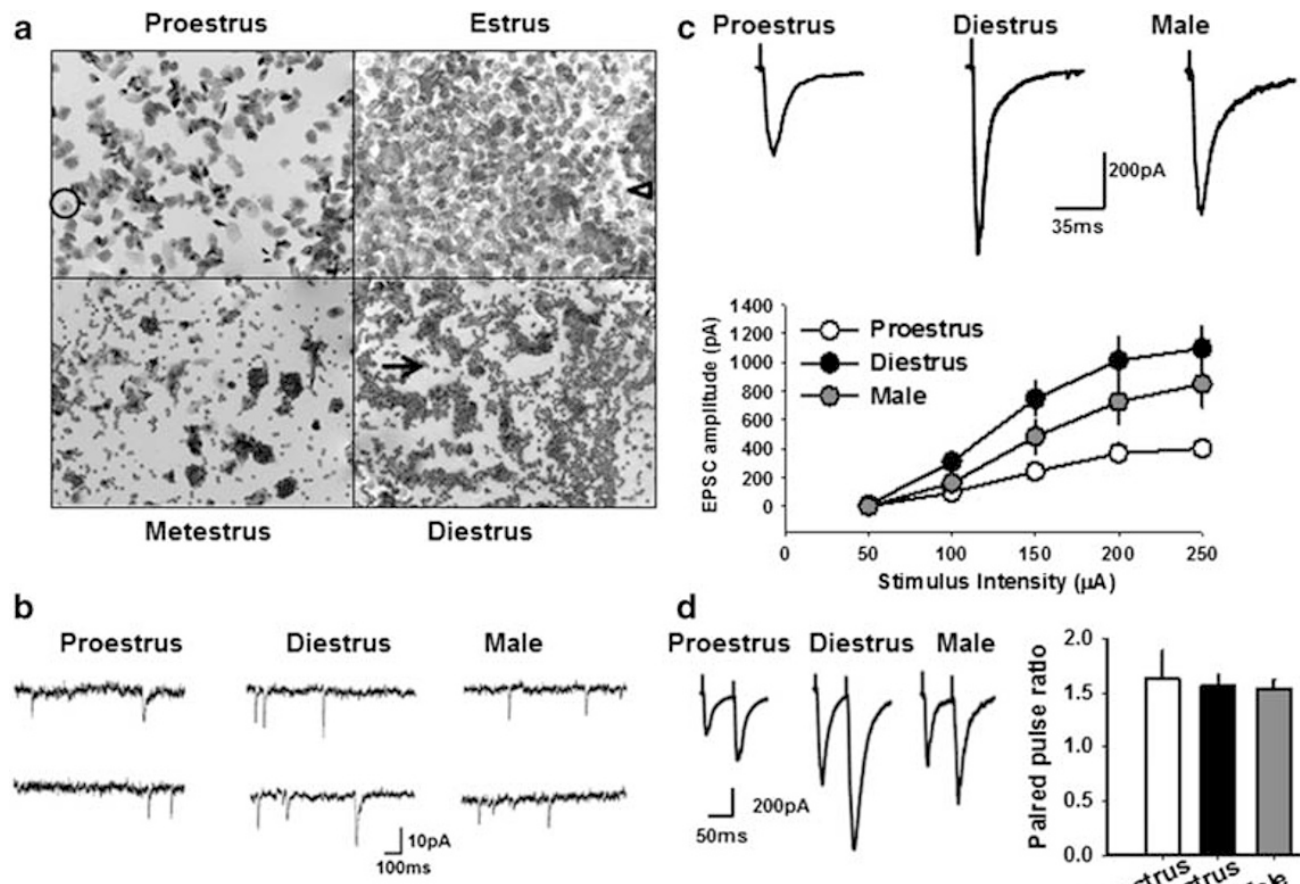

d
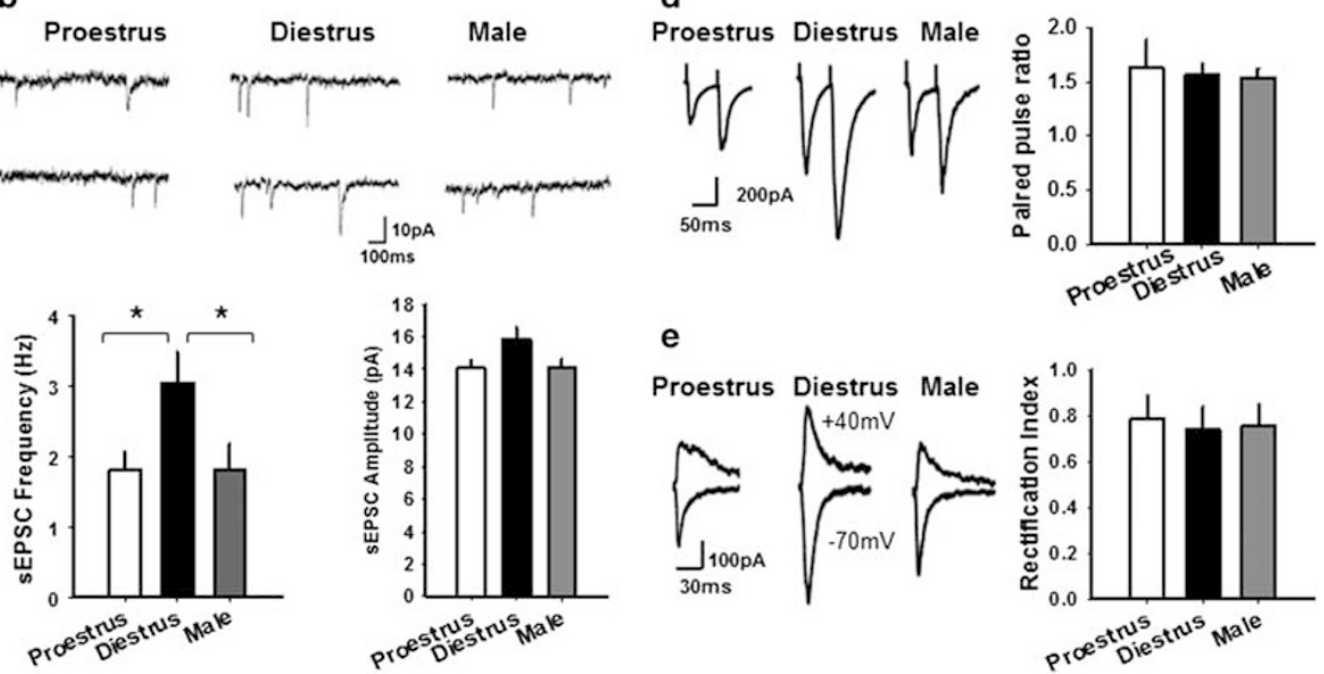

e
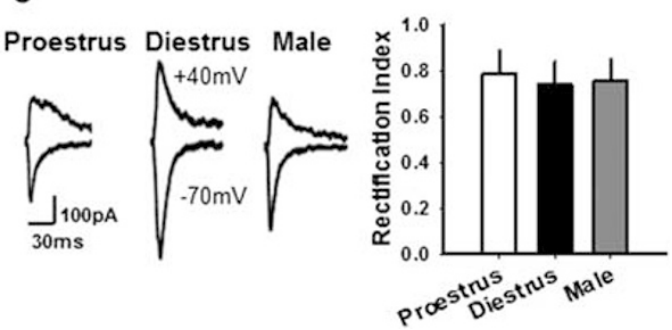

Figure I Non-NMDA receptor transmission in the IL-mPFC layer 5 pyramidal neurons. (a) Representative images of vaginal cytology in proestrus, estrus, metestrus, and diestrus mice showing nucleated epithelial cells (circle), cornified epithelial cells (arrow head), and leukocytes (arrow). (b) sEPSC frequency and amplitude in proestrus $(n=17 / 6$ mice), diestrus $(n=16 / 6$ mice), and male $(n=15 / 5$ mice) mice. Upper panel shows examples of sEPSCs. Asterisk indicates a significant difference. (c) EPSC amplitude in proestrus ( $n=15 / 5$ mice), diestrus $(n=15 / 5$ mice), and male mice $(n=13 / 5$ mice). Upper panel shows examples of EPSCs evoked by $250 \mu$ A stimulation. (d) Paired pulse ratio in proestrus ( $n=9 / 3$ mice), diestrus $(n=7 / 3$ mice), and male mice ( $n=8 / 3$ mice). Left panel shows examples of EPSCs evoked at $60 \mathrm{~ms}$ interval. (e) Rectification index in proestrus $(n=6 / 3$ mice), diestrus ( $n=7 / 3$ mice), and male mice $(n=7 / 4$ mice). Left panel shows examples of EPSCs evoked at $-70 \mathrm{mV}$ and $+40 \mathrm{mV}$. 
(PPF) (Hess et al, 1987; Zucker, 1989). Paired pulse ratio was measured by $150 \mu \mathrm{A}$ stimulation at an inter-stimulus interval of $60 \mathrm{~ms}$. Rectification index was assessed by calculating the ratio of the slope of the lines connecting EPSC amplitudes at -70 to 0 and 0 to $+40 \mathrm{mV}$ in the presence of bicuculline and D-2-Amino-5-phosphonovaleric acid (APV, $50 \mu \mathrm{M}$ ) in the extracellular solution and spermine $(0.1 \mathrm{mM})$ in the pipette solution (Adesnik and Nicoll, 2007). Excitatory post-synaptic potentials (EPSPs) were recorded at $0.1 \mathrm{~Hz}$ and a pre-beforepost pairing protocol was applied after a stable baseline recording for $5 \mathrm{~min}$ (Froemke and Dan, 2002; Pattwell et al, 2012a). Input resistance was monitored throughout the experiment. Recording was acquired using Axopatch 200B amplifier and digitized by Digidata 1322A (Molecular Devices). Data were analyzed using Clampfit (Molecular Devices) and Mini Analysis software (Synaptosoft Inc.).

\section{Drug Administration}

Diarylpropionitrile (DPN, a selective $\operatorname{ER} \beta$ agonist) (Sigma, $1 \mathrm{mg} / \mathrm{kg}$ ), propyl pyrazole triol (PPT, a selective ER $\alpha$ agonist) (Sigma, $1 \mathrm{mg} / \mathrm{kg}$ ), or vehicle (sesame oil) were injected subcutaneously $90-120 \mathrm{~min}$ before the slice preparation. We used a modified treatment regimen for estradiol and progesterone based on the earlier studies in ovary-intact and ovariectomized rats (Chang et al, 2009; Milad et al, 2009; Zeidan et al, 2011). Ovariectomized and sham mice received two injections of estradiol (Sigma, $15 \mu \mathrm{g} / \mathrm{kg}$ ), progesterone (Sigma, $4 \mathrm{mg} / \mathrm{kg}$ ), or vehicle (sesame oil) at an interval of $16-18 \mathrm{~h}$, and the last dose was injected 90-120 min before the slice preparation.

\section{Statistical Analysis}

Data are presented as mean \pm SEM. One-way ANOVA followed by least significant difference (LSD) post hoc test was used for comparing sEPSCs and NMDA mEPSCs. Repeated measure ANOVA followed by Bonferroni test was used for comparing EPSCs and EPSP slope. GreenhouseGeisser correction was applied when sphericity was violated. $P<0.05$ was considered statistically significant.

\section{RESULTS}

\section{Estrous Cycle-Dependent Modulation of Non-NMDA Receptor Synaptic Transmission in the IL-mPFC}

To test whether endogenous estradiol modulates the ILmPFC glutamatergic synapses, we studied AMPA receptormediated non-NMDA receptor transmission in the IL-mPFC layer 5 pyramidal neurons, from proestrus and diestrus mice. Male mice were included for comparison. We observed a significant effect of groups on sEPSC frequency $\left(\mathrm{F}_{(2,45)}=4.02, \quad p=0.025\right) \quad$ but not on amplitude $\left(\mathrm{F}_{(2,45)}=2.95, p=0.062\right)$ (Figure $\left.1 \mathrm{~b}\right)$. sEPSC frequency in diestrus mice was significantly higher than that in proestrus $(p=0.016)$ and male mice $(p=0.02)$. Comparison of EPSC amplitude in proestrus, diestrus, and male mice revealed a main effect of group $\left(\mathrm{F}_{(2,40)}=7.71, p=0.001\right)$, stimulus intensity $\left(\mathrm{F}_{(1.2,47.9)}=80.95, p<0.001\right)$, and interaction between factors $\left(\mathrm{F}_{(2.4,47.9)}=5.73, p=0.004\right)$, suggesting that
non-NMDA receptor transmission is elevated in diestrus compared with proestrus and male mice (Figure 1c).

Modification of synaptic transmission could occur through pre- and/or post-synaptic mechanisms. To test the role of pre-synaptic mechanism, we compared paired pulse ratio in proestrus, diestrus, and male mice. A statistically significant effect of time $\left(\mathrm{F}_{(1,22)}=22.98, p<0.001\right)$ but a non-significant effect of groups $\left(\mathrm{F}_{(2,22)}=1.972, p=0.163\right)$ and interaction between factors $\left(\mathrm{F}_{(2,22)}=1.269, p=0.301\right)$ (Figure 1d) suggested that a modification of glutamate release is unlikely to be responsible for differences in non-NMDA receptor transmission in proestrus, diestrus, and male mice. Another potential mechanism for an increase in the strength of cortical glutamatergic synapses is synaptic insertion of GluA2 subunit-lacking AMPA receptors, which are inwardly rectifying unlike GluA2-containing AMPA receptors (Adesnik and Nicoll, 2007). Comparison of the slope of the lines connecting EPSC amplitudes at -70 to 0 and 0 to $+40 \mathrm{mV}$ showed a statistically significant effect of holding potential $\left(\mathrm{F}_{(1,17)}=\right.$ 12.79, $p=0.002$ ) but a non-significant effect of groups $\left(\mathrm{F}_{(2,17)}=0.808, p=0.462\right)$ and interaction between factors $\left(\mathrm{F}_{(2,17)}=0.266, p=0.77\right)$ (Figure $1 \mathrm{e}$ ), suggesting that the difference in non-NMDA receptor transmission between proestrus, diestrus, and male mice is mediated by GluA2containing AMPA receptors that are not inwardly rectifying.

\section{Reduced GluN2B-Mediated NMDA Receptor Transmission in Diestrus Mice}

We compared NMDA receptor transmission in proestrus, diestrus, and male groups by measuring NMDA mEPSCs, which did not show a statistically significant difference in frequency $\left(\mathrm{F}_{(2,31)}=2.5, p=0.098\right)$ or amplitude $\left(\mathrm{F}_{(2,31)}=2.67\right.$, $p=0.085)$. However, a significant difference in NMDA mEPSC decay time was observed $\left(\mathrm{F}_{(2,31)}=17.2, p<0.001\right)$ (Figure $\left.2 \mathrm{a}\right)$. Decay time was significantly reduced in diestrus mice compared with that in proestrus $(p<0.001)$ and male mice $(p<0.001)$. Consistent with the NMDA mEPSC decay time, NMDA EPSC decay time also showed a significant effect $\left(F_{(2,31)}=4.36, p=0.022\right)$ with the proestrus group exhibiting a significantly higher decay time compared with the diestrus group $(p=0.006)$, an indication of GluN2B-predominant NMDA receptor transmission (Cull-Candy et al, 2001). Therefore, we compared NMDA EPSC decay time in proestrus, diestrus, and male groups before and after the perfusion of ifenprodil, a highly selective GluN2B antagonist (Williams, $1993)$, which showed a main effect of time $\left(F_{(1,29)}=154.874\right.$, $p<0.001)$, a non-significant effect of groups $\left(\mathrm{F}_{(2,29)}=2.357\right.$, $p=0.113)$, and a significant interaction between factors $\left(\mathrm{F}_{(2,29)}=7.892, p=0.002\right.$ ) (Figure $\left.2 \mathrm{~b}\right)$. Analysis of NMDA EPSC amplitude revealed a main effect of time $\left(\mathrm{F}_{(1,29)}=93.196\right.$, $p<0.001)$, a non-significant effect of groups $\left(\mathrm{F}_{(2,29)}=2.728\right.$, $p=0.082)$, and a significant interaction between factors $\left(\mathrm{F}_{(2,29)}=5.797, p=0.008\right)$ (Figure $\left.2 \mathrm{~b}\right)$. These results confirmed a reduced GluN2B-mediated NMDA receptor transmission in diestrus mice compared with proestrus and male mice.

\section{Estrous Cycle-Dependent Regulation of Synaptic Plasticity in the IL-mPFC}

Given the estrous cycle-dependent modulation of NMDA receptor transmission, a key determinant of synaptic 
a
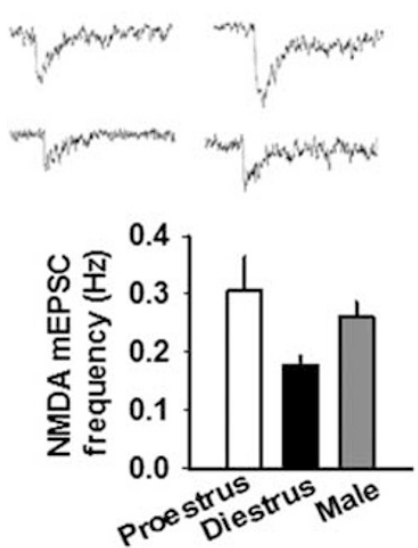

b
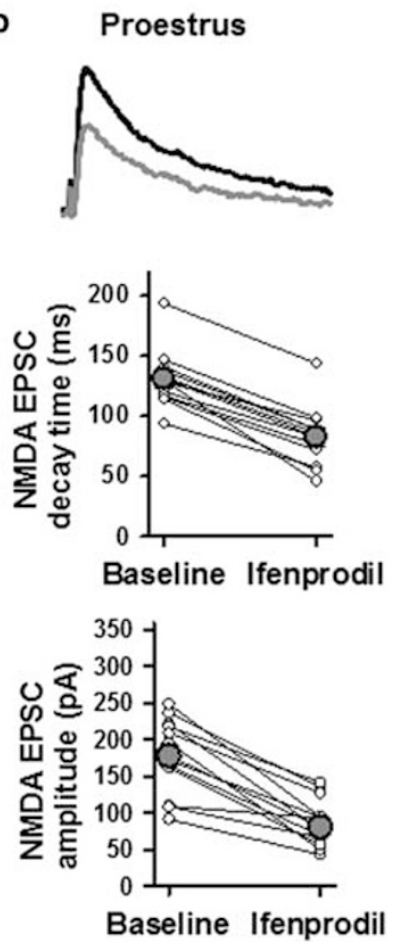

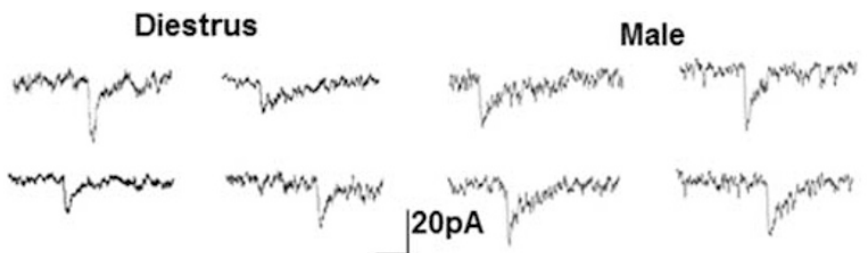

$60 \mathrm{~ms}$
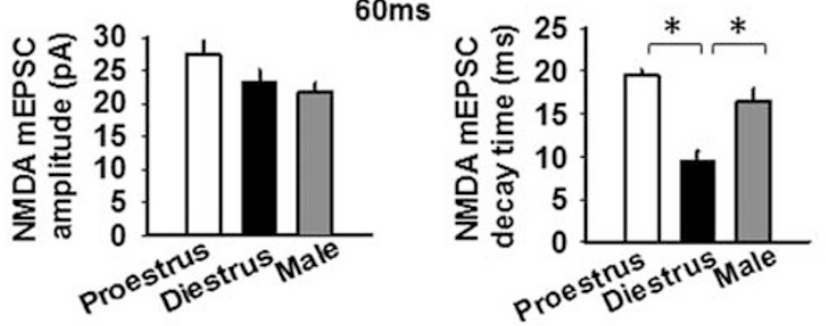

Diestrus

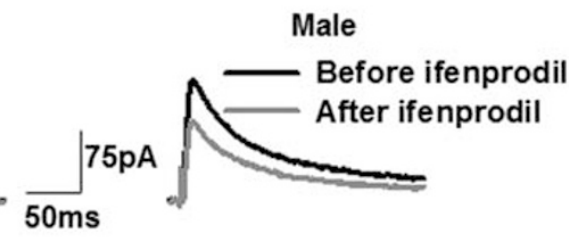

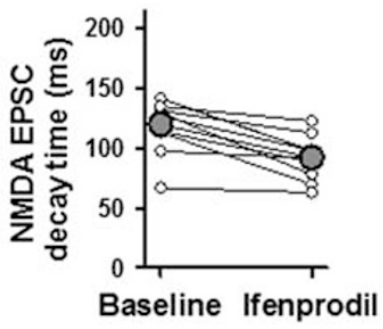
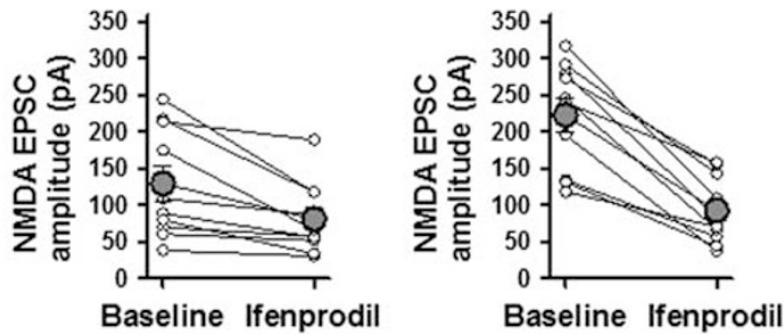

Figure 2 NMDA receptor transmission in the IL-mPFC layer 5 pyramidal neurons. (a) Frequency, amplitude and decay time of NMDA mEPSCs in proestrus $(n=11 / 4$ mice), diestrus $(n=10 / 4$ mice), and male mice $(n=13 / 6$ mice). Upper panel shows examples of NMDA mEPSCs. Asterisk indicates a significant difference. (b) Effect of ifenprodil on NMDA EPSC decay time and amplitude in proestrus ( $n=12 / 4$ mice), diestrus ( $n=10 / 4$ mice), and male mice $(n=10 / 4$ mice). Small empty and large filled circles represent raw data and mean \pm SEM, respectively. Upper panel shows examples of NMDA EPSCs before and $15 \mathrm{~min}$ after ifenprodil perfusion.

plasticity, we examined long-lasting synaptic potentiation in proestrus, diestrus, and male mice. The application of a pre-before-post pairing protocol produced a long-term enhancement of EPSP slope in the proestrus group, which was blocked by ifenprodil. A main effect of groups $\left(\mathrm{F}_{(2,21)}=10.846, p=0.001\right)$, a non-significant effect of time $\left(\mathrm{F}_{(29,609)}=0.807, p=0.754\right)$, and a significant interaction between factors $\left(\mathrm{F}_{(58,609)}=4.779, p<0.001\right)$ were observed (Figure 3a). However, the same pairing protocol produced a long-lasting depression of EPSP slope in the diestrus group, which was not sensitive to ifenprodil. A non-significant effect of groups $\left(\mathrm{F}_{(2,23)}=1.312, p=0.289\right)$, a significant effect of time $\left(\mathrm{F}_{(29,667)}=3.705, p<0.001\right)$, and a significant interaction between factors $\left(\mathrm{F}_{(58,667)}=1.525, p=0.009\right)$ were observed (Figure $3 \mathrm{~b}$ ). Similar to the proestrus group, pairing produced a long-lasting increase in EPSP slope in male mice, which was blocked by ifenprodil as shown by a main effect of groups $\left(\mathrm{F}_{(2,22)}=28.747, p<0.001\right)$, a nonsignificant effect of time $\left(\mathrm{F}_{(29,638)}=0.938, p=0.562\right)$, and a significant interaction between factors $\left(\mathrm{F}_{(58,638)}=2.219\right.$, $p<0.001$ ) (Figure 3c). These results suggest that GluN2Bmediated NMDA receptor transmission is critical for synaptic potentiation in the IL-mPFC of proestrus and male mice, and it is impaired in the diestrus mice. 

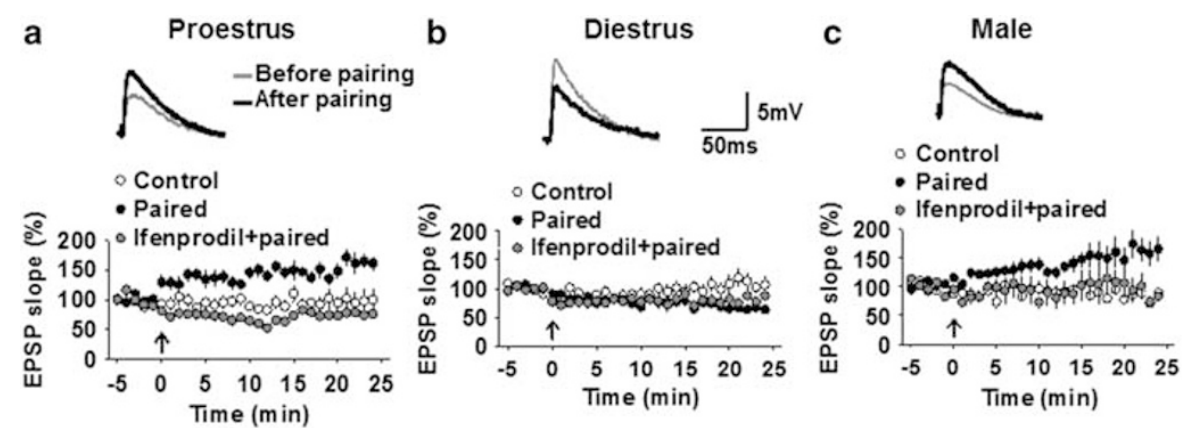

Figure 3 Synaptic plasticity in the IL-mPFC layer 5 pyramidal neurons. (a) Percentage changes in EPSP slope in unpaired proestrus ( $n=7 / 4$ mice), paired proestrus ( $n=10 / 5$ mice), and ifenprodil + paired proestrus groups $(n=7 / 5$ mice). (b) Percentage changes in EPSP slope in unpaired diestrus ( $n=7 / 4$ mice), paired diestrus ( $n=11 / 7$ mice), and ifenprodil + paired diestrus groups $(n=8 / 5$ mice). (c) Percentage changes in EPSP slope in unpaired male ( $n=7 /$ 4 mice), paired male $(n=10 / 5$ mice), and ifenprodil + paired male groups $(n=8 / 4$ mice). Arrow represents the application of the pairing protocol. Upper panel shows examples of EPSPs before and after the pairing protocol.

\section{Differential Effects of ER $\beta$ Activation on the IL-mPFC Synapses in Proestrus and Diestrus Mice}

To understand whether ER $\beta$ activation exerts similar effects as endogenous estradiol on the IL-mPFC glutamatergic synapses, we examined non-NMDA EPSCs in vehicle- and DPN-treated proestrus and diestrus mice. A main effect of groups $\left(\mathrm{F}_{(3,32)}=7.376, p=0.001\right)$, a significant effect of stimulus intensity $\left(\mathrm{F}_{(1.2,40.9)}=84.65, p<0.001\right)$, and a significant interaction between factors $\left(\mathrm{F}_{(3.8,40.9)}=5.05\right.$, $p=0.002$ ) were observed (Figure 4a). Whereas DPN treatment increased the EPSC amplitude in proestrus mice $(p=0.031)$, EPSC amplitude was suppressed in diestrus mice following DPN treatment $(p=0.007)$ (Figure 4a). To test whether DPN-induced changes in synaptic transmission involves modulation of glutamate release, we compared PPF in vehicle- and DPN-treated proestrus and diestrus groups, which showed a main effect of groups $\left(\mathrm{F}_{(3,32)}=6.323\right.$, $p=0.002)$, a significant effect of time $\left(\mathrm{F}_{(1,32)}=10.493\right.$, $p=0.003)$, and a non-significant interaction between factors $\left(\mathrm{F}_{(3,32)}=2.358, p=0.09\right)$ (Figure $\left.4 \mathrm{~b}\right)$. Thus, the increase in EPSC amplitude in DPN-treated proestrus mice was mediated by an enhanced glutamate release. However, $\operatorname{ER} \beta$ activation suppressed glutamate release in the diestrus group and prevented any further facilitation in response to the second stimulus.

Next, we asked whether the activation of $\operatorname{ER} \beta$ has an effect on GluN2B-mediated transmission in diestrus mice. We observed a significantly higher NMDA EPSC decay time in the DPN-treated diestrus group compared with vehicletreated group $\left(\mathrm{t}_{(16)}=2.22, p=0.041\right)$. Comparison of the effect of ifenprodil on NMDA EPSC decay time in vehicleand DPN-treated diestrus mice showed a main effect of groups $\left(\mathrm{F}_{(1,16)}=5.521, p=0.032\right)$, a significant effect of time $\left(\mathrm{F}_{(1,16)}=17.548, p=0.001\right)$, and a non-significant interaction between factors $\left(\mathrm{F}_{(1,16)}=2.998, p=0.103\right)$ (Figure 4c). Comparison of NMDA EPSC amplitude revealed a nonsignificant effect of groups $\left(\mathrm{F}_{(1,16)}=0.201, p=0.66\right)$, a significant effect of time $\left(\mathrm{F}_{(1,16)}=24, p<0.001\right)$, and a non-significant interaction between factors $\left(\mathrm{F}_{(1,16)}=1.126\right.$, $p=0.304$ ) (Figure $4 \mathrm{~d}$ ). The ifenprodil-sensitive increase in decay time by DPN suggests that $\operatorname{ER} \beta$ activation facilitates GluN2B-mediated transmission in diestrus mice.
DPN-treated diestrus mice showed a significant synaptic potentiation in an ifenprodil-sensitive manner after the prebefore-post pairing as shown by a main effect of groups $\left(\mathrm{F}_{(2,23)}=21.426, \quad p<0.001\right)$, a significant effect of time $\left(\mathrm{F}_{(29,667)}=2.385, p<0.001\right)$, and a significant interaction between factors $\left(\mathrm{F}_{(58,667)}=4.123, p<0.001\right)$ (Figure $4 \mathrm{e}$ ). Thus, ER $\beta$ activation restores synaptic potentiation in diestrus mice by a GluN2B-dependent mechanism. The rescue of synaptic potentiation in diestrus mice is selective to $\mathrm{ER} \beta$ but not $\mathrm{ER} \alpha$ activation as PPT, an $\mathrm{ER} \alpha$ agonist, failed to affect EPSP slope in diestrus mice as shown by a non-significant effect of groups $\left(\mathrm{F}_{(1,16)}=1.334, p=0.265\right)$, a significant effect of time $\left(\mathrm{F}_{(29,464)}=4.029, p<0.001\right)$, and a non-significant interaction between factors $\left(\mathrm{F}_{(29,464)}=\right.$ $1.254, p=0.173$ ) (Figure 4e). Surprisingly, DPN blocked synaptic potentiation in the proestrus group as shown by a main effect of groups $\left(\mathrm{F}_{(1,11)}=9.789, p=0.007\right)$, a nonsignificant effect of time $\left(\mathrm{F}_{(29,406)}=0.923, p=0.583\right)$, and a significant interaction between factors $\left(\mathrm{F}_{(29,406)}=1.873\right.$, $p=0.005$ ) (Figure $4 \mathrm{f}$ ). Thus, $\operatorname{ER} \beta$ activation exerts opposite effect on synaptic potentiation in proestrus and diestrus mice.

\section{Exogenous Estradiol Enhances Non-NMDA Receptor Transmission in the IL-mPFC}

As both estradiol and progesterone are elevated during proestrus (DeLeon et al, 1990), we examined which of these hormones mimic glutamatergic transmission during proestrus and whether ovariectomy exerts a similar effect as low endogenous estradiol on glutamatergic transmission. Although ovariectomy did not affect EPSC amplitude, administration of estradiol enhanced the EPSC amplitude in both ovariectomized and sham mice as revealed by a main effect of group $\left(\mathrm{F}_{(3,30)}=19.16, p<0.001\right)$, stimulus intensity $\left(\mathrm{F}_{(1.5,44.6)}=67.73, p<0.001\right)$, and a significant interaction between factors $\left(\mathrm{F}_{(4.5,44.6)}=2.561, p=0.046\right)$ (Figure 5a). Comparison of PPF in estradiol- and vehicletreated ovariectomized and sham mice showed a significant effect of groups $\left(\mathrm{F}_{(3,30)}=10.35, p<0.001\right)$, a significant effect of time $\left(\mathrm{F}_{(1,30)}=18.75, p<0.001\right)$, and a non-significant interaction between factors $\left(\mathrm{F}_{(3,30)}=1.232, p=0.315\right)$ (Figure $5 \mathrm{~b}$ ), suggesting that estradiol enhances EPSC amplitude by a 
a

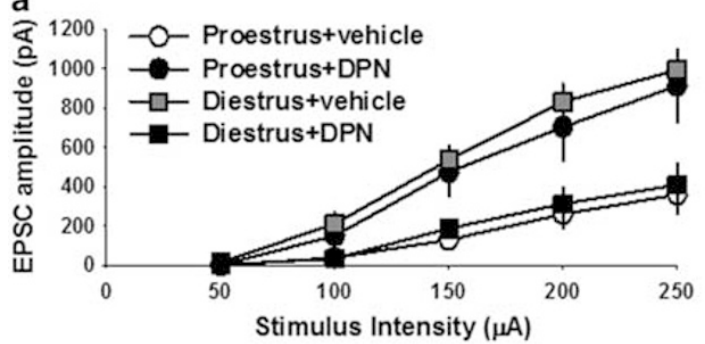

b

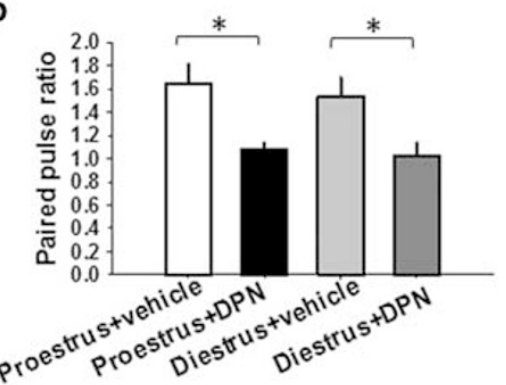

C

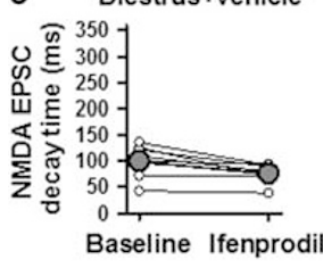

Diestrus+DPN

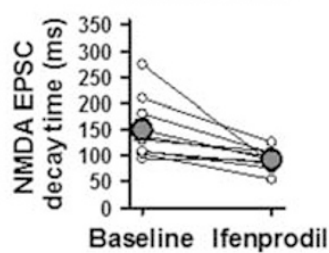

d Diestrus+vehicle

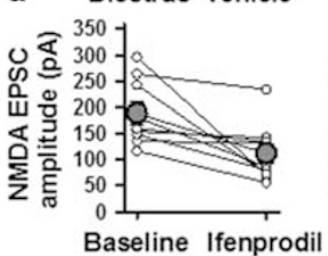

Diestrus+DPN

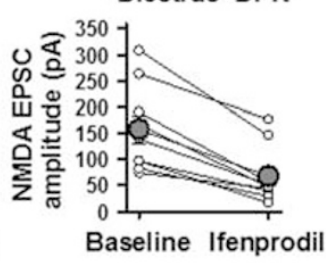

Proestrus

- Vehicle

- DPN e

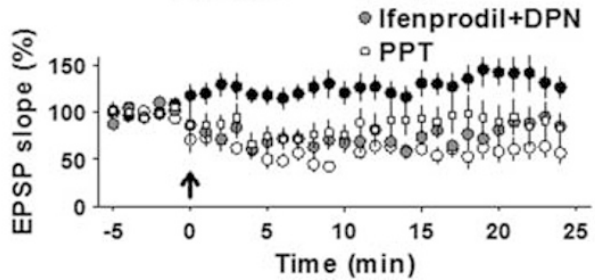

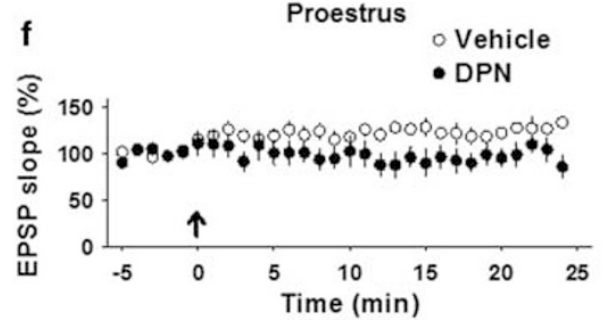

Figure 4 Effect of ER $\beta$ activation on the IL-mPFC glutamatergic synapses. Non-NMDA EPSC amplitude (a) and paired pulse ratio (b) in proestrus + vehicle $(n=8 / 4$ mice), proestrus + DPN $(n=9 / 4$ mice), diestrus + vehicle $(n=9 / 4$ mice $)$, and diestrus + DPN groups $(n=10 / 4$ mice). Asterisk indicates a significant difference. Effect of ifenprodil on NMDA EPSC decay time (c) and amplitude (d) in vehicle- $(n=9 / 4$ mice) and DPN-treated diestrus mice ( $n=9 /$ 4 mice). Small empty and large filled circles represent raw data and mean \pm SEM, respectively. (e) Percentage changes in EPSP slope in paired vehicle-treated ( $n=10 / 5$ mice), paired DPN-treated ( $n=9 / 5$ mice), paired ifenprodil + DPN-treated $(n=7 / 4$ mice), and paired PPT-treated diestrus mice $(n=8 / 4$ mice). (f) Percentage changes in EPSP slope in paired vehicle-treated $(n=8 / 5$ mice) and paired DPN-treated proestrus mice $(n=8 / 4$ mice). Arrow represents the application of the pairing protocol.
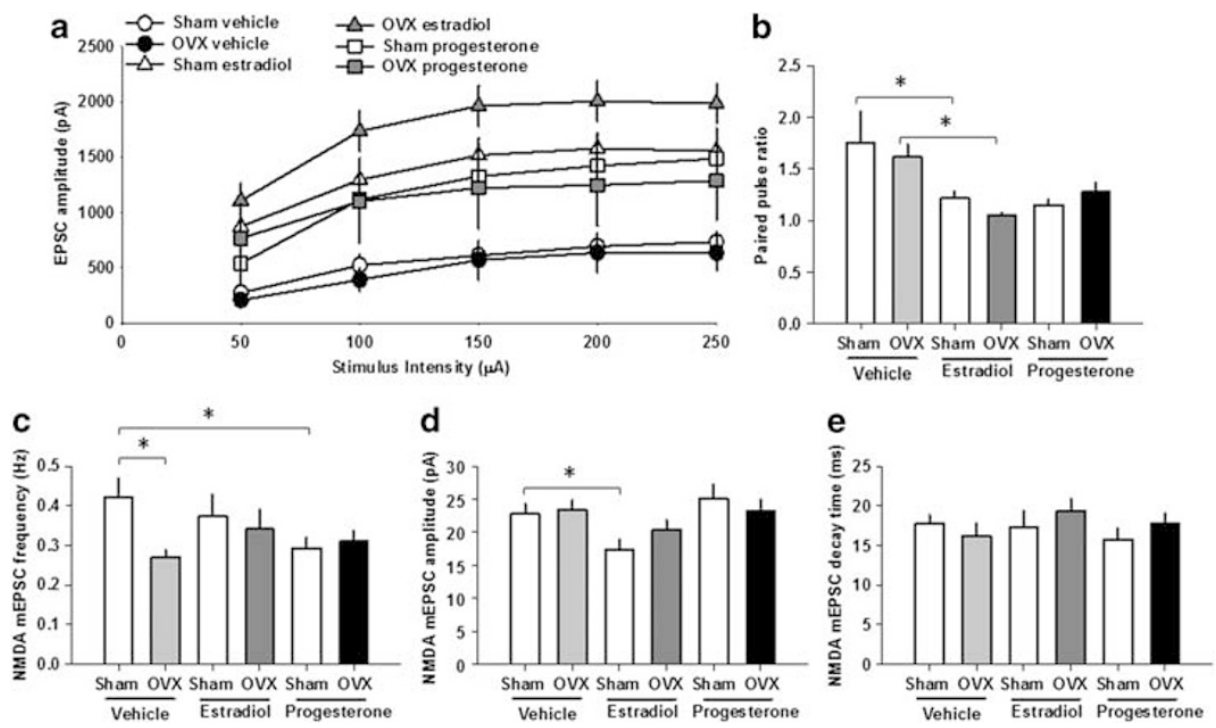

Figure 5 Effect of exogenous estradiol and progesterone on the IL-mPFC glutamatergic synapses. EPSC amplitude (a) and PPF (b) in vehicle-treated sham $(n=8 / 3$ mice), vehicle-treated ovariectomized $(O V X)(n=9 / 3$ mice), estradiol-treated sham $(n=9 / 3$ mice), estradiol-treated ovariectomized mice $(n=8 / 3$ mice), progesterone-treated sham $(n=9 / 3$ mice), and progesterone-treated ovariectomized mice $(n=9 / 3$ mice). NMDA mEPSC frequency (c), amplitude (d), and decay time (e) in vehicle-treated sham ( $n=9 / 3$ mice), vehicle-treated ovariectomized ( $n=9 / 3$ mice), estradiol-treated sham ( $n=9 / 3$ mice), estradiol-treated ovariectomized ( $n=9 / 3$ mice), progesterone-treated sham $(n=9 / 3$ mice), and progesterone-treated ovariectomized mice $(n=9 / 3$ mice). Asterisk indicates a significant difference. 
pre-synaptic mechanism. EPSC amplitude in vehicle- and progesterone-treated ovariectomized and sham mice showed a non-significant effect of group $\left(\mathrm{F}_{(3,31)}=2.404, p=0.086\right)$, a significant effect of stimulus intensity $\left(\mathrm{F}_{(1.6,49.7)}=49, p<0.001\right)$, and a non-significant interaction between factors $\left(\mathrm{F}_{(4.8,49.7)}=2.153, p=0.077\right)$ (Figure 5a). Consistently, we observed a non-significant effect of groups $\left(\mathrm{F}_{(3,31)}=1.32\right.$, $p=0.286), \quad a$ significant effect of time $\left(\mathrm{F}_{(1,31)}=16\right.$, $p<0.001)$, and a non-significant interaction between factors $\left(\mathrm{F}_{(3,31)}=1.852, p=0.158\right)$ when PPF was compared between progesterone- and vehicle-treated ovariectomized and sham mice (Figure 5b). Thus, in contrast to the decreased non-NMDA receptor transmission in proestrus, exogenous estradiol enhanced EPSC amplitude, whereas neither ovariectomy nor progesterone produced a significant effect.

Next, we compared the effect of exogenous estradiol and progesterone on NMDA receptor transmission. Although the ovariectomized mice showed a decrease in NMDA mEPSC frequency compared with sham group $\left(\mathrm{t}_{(16)}=2.93\right.$, $p=0.009$ ), both the amplitude and decay time remained unaffected. Exogenous estradiol did not affect frequency $\left(\mathrm{F}_{(3,32)}=1.965, p=0.139\right)$ or decay time $\left(\mathrm{F}_{(3,32)}=0.671\right.$, $p=0.576$ ) (Figure $5 c$ and e). However, a main effect on NMDA mEPSC amplitude was observed $\left(\mathrm{F}_{(3,32)}=3.257\right.$, $p=0.034)$ with a significant suppression of NMDA mEPSC amplitude in estradiol-treated sham mice $(p=0.018)$ (Figure 5d). Unlike estradiol, progesterone did not affect the amplitude $\left(\mathrm{F}_{(3,32)}=0.37, p=0.775\right)$ but showed an effect on NMDA mEPSC frequency $\left(\mathrm{F}_{(3,32)}=4.332, p=0.011\right)$ with a significant suppression in sham mice $(p=0.008)$ (Figure $5 \mathrm{c}$ and $\mathrm{d}$ ). Similar to estradiol, progesterone did not affect decay time of NMDA mEPSCs $\left(\mathrm{F}_{(3,32)}=0.608\right.$, $p=0.615$ ) (Figure 5e). Thus, exogenous administration of neither estradiol nor progesterone mimics NMDA receptor transmission in proestrus mice but exerts a suppression of NMDA receptor transmission in ovary-intact mice.

\section{DISCUSSION}

Here we demonstrate an estrous cycle-dependent modulation of glutamatergic synaptic transmission and plasticity in the IL-mPFC. In contrast to the effect of exogenous estradiol, which showed an enhancement of non-NMDA receptor transmission, proestrus mice exhibited a reduced non-NMDA receptor transmission compared with diestrus and male mice. Also, the activation of ER $\beta$ exerted an opposite effect on non-NMDA receptor transmission in diestrus and proestrus mice, a suppression and potentiation, respectively. While the exogenous activation of estradiol signaling modulated glutamate release, synaptic GluA2-containing AMPA receptors might be responsible for the differences in non-NMDA receptor transmission in proestrus, diestrus, and male mice as we did not observe any modification of PPF or inward rectification of EPSCs, a hallmark of synaptic GluA2-lacking AMPA receptors (Adesnik and Nicoll, 2007). Circulating estradiol level might have a role in the differential effects of endogenous and exogenous estradiol on non-NMDA receptor transmission.

The metaplasticity induced by the endogenous estradiol appears to define a temporal window for enhanced synaptic potentiation in a GluN2B-dependent manner. The enhancement of GluN2B NMDA receptor transmission by estradiol signaling might involve synaptic recruitment of GluN2B-containing NMDA receptors (Snyder et al, 2011). Estradiol-mediated enhancement of GluN2B function and synaptic plasticity have been reported in other brain areas (Smith and McMahon, 2006; Snyder et al, 2011; Xiao et al, 2013). Given the role of brain-derived neurotrophic factor (BDNF) downstream of estradiol signaling and its effect on GluN2B-mediated transmission, BDNF might be involved in estradiol-induced augmentation of GluN2B transmission (Levine and Kolb, 2000; Miranda et al, 1994). The attenuation of NMDA receptor transmission by exogenous estradiol and progesterone suggests the possibility that the beneficial effects of exogenous estradiol and progesterone in fear extinction might be mediated by its effect on brain areas other than the IL-mPFC, which might include the hippocampus and amygdala (Milad et al, 2009). Consistently, exogenous estradiol was shown to exert a selective effect on BDNF signaling in the hippocampus compared with the cortex (Singh et al, 1995).

The aforementioned metaplasticity causes enhanced glutamate release by $\operatorname{ER} \beta$ activation during periods of high endogenous estradiol, which occludes a subsequent activitydependent synaptic potentiation. However, during periods of low endogenous estradiol, ER $\beta$ activation suppresses basal transmission but facilitates activity-dependent potentiation by enhancing GluN2B transmission. A recent study showed that dopamine $\mathrm{D}_{1}$ receptor activation impaired fear extinction during periods of high endogenous estradiol but reversed fear extinction deficits during periods of low endogenous estradiol (Rey et al, 2013). Consistently, estradiol was reported to suppress and enhance hippocampal long-term potentiation in proestrus and diestrus rats, respectively (Foy et al, 2008). Therefore, endogenous estradiol level might have a critical role in determining how the IL-mPFC synapses respond to not only exogenous estradiol and progesterone but also neuromodulators such as dopamine. It is unclear whether local synthesis of estradiol has a role in the IL-mPFC. Sex difference in the expression of aromatase, the biosynthetic enzyme for estradiol, and its effect on prefrontal cortical functions warrant future studies to understand the regulation and function of local synthesis of estradiol in the IL-mPFC (Wei et al, 2013; Xiao et al, 2013).

Comparable fear extinction and the IL-mPFC synaptic plasticity in male and high estradiol females suggest that endogenous estradiol level might be a key to sex difference in IL-mPFC function and fear extinction (Milad et al, 2010). The IL-mPFC-mediated top-down regulation of the amygdala, a mechanism believed to control fear extinction, involves synaptic potentiation in the IL-mPFC (Pare et al, 2004; Pattwell et al, 2012b; Sepulveda-Orengo et al, 2013). Therefore, the estradiol-dependent facilitation of synaptic potentiation in the IL-mPFC might contribute significantly to the enhancement of fear extinction (Chang et al, 2009; Zeidan et al, 2011). Also, GluN2B-mediated synaptic transmission might be an effective alternative to augment the IL-mPFC plasticity and fear extinction, which is consistent with the unique role of GluN2B-mediated NMDA receptor transmission in the mPFC (Flores-Barrera et al, 2013; Wang et al, 2008). Thus, our findings provide important insights into not only the synaptic mechanism by which estradiol 
signaling could modulate the IL-mPFC synapses but also potential molecular targets for fear-related psychiatric disorders.

\section{FUNDING AND DISCLOSURE}

This work was supported by NIH (RO1 MH96899). The authors declare no conflict of interest.

\section{ACKNOWLEDGEMENTS}

We thank Dr Francis S. Lee, Dr Teresa A. Milner, and Iva Dincheva (Weill Cornell Medical College) for helpful suggestions.

\section{REFERENCES}

Adesnik H, Nicoll RA (2007). Conservation of glutamate receptor 2-containing AMPA receptors during long-term potentiation. J Neurosci 27: 4598-4602.

Altshuler LL, Hendrick V, Cohen LS (1998). Course of mood and anxiety disorders during pregnancy and the postpartum period. J Clin Psychiatry 59(Suppl 2): 29-33.

Angold A, Costello EJ, Worthman CM (1998). Puberty and depression: the roles of age, pubertal status and pubertal timing. Psychol Med 28: 51-61.

Byers SL, Wiles MV, Dunn SL, Taft RA (2012). Mouse estrous cycle identification tool and images. PLOS ONE 7: e35538.

Chang YJ, Yang CH, Liang YC, Yeh CM, Huang CC, Hsu KS (2009). Estrogen modulates sexually dimorphic contextual fear extinction in rats through estrogen receptor beta. Hippocampus 19: $1142-1150$.

Cull-Candy S, Brickley S, Farrant M (2001). NMDA receptor subunits: diversity, development and disease. Curr Opin Neurobiol 11: 327-335.

Davis M (2011). NMDA receptors and fear extinction: implications for cognitive behavioral therapy. Dialogues Clin Neurosci 13: 463-474.

DeLeon DD, Zelinski-Wooten MB, Barkley MS (1990). Hormonal basis of variation in oestrous cyclicity in selected strains of mice. J Reprod Fertil 89: 117-126.

Flores-Barrera E, Thomases DR, Heng LJ, Cass DK, Caballero A, Tseng KY (2013). Late adolescent expression of GluN2B transmission in the prefrontal cortex is input-specific and requires postsynaptic protein kinase $\mathrm{A}$ and $\mathrm{D} 1$ dopamine receptor signaling. Biol Psychiatry 75: 508-516.

Foy MR, Baudry M, Diaz Brinton R, Thompson RF (2008). Estrogen and hippocampal plasticity in rodent models. J Alzheimer's Dis 15: 589-603.

Froemke RC, Dan Y (2002). Spike-timing-dependent synaptic modification induced by natural spike trains. Nature 416: 433-438.

Gabbott PL, Warner TA, Jays PR, Salway P, Busby SJ (2005). Prefrontal cortex in the rat: projections to subcortical autonomic, motor, and limbic centers. J Comp Neurol 492: 145-177.

Hall JM, Couse JF, Korach KS (2001). The multifaceted mechanisms of estradiol and estrogen receptor signaling. J Biol Chem 276: 36869-36872.

Hankin BL, Abramson LY (1999). Development of gender differences in depression: description and possible explanations. Ann Med 31: 372-379.

Harsh V, Meltzer-Brody S, Rubinow DR, Schmidt PJ (2009). Reproductive aging, sex steroids, and mood disorders. Harv Rev Psychiatry 17: 87-102.
Hess G, Kuhnt U, Voronin LL (1987). Quantal analysis of pairedpulse facilitation in guinea pig hippocampal slices. Neurosci Lett 77: 187-192.

Holbrook TL, Hoyt DB, Stein MB, Sieber WJ (2002). Gender differences in long-term posttraumatic stress disorder outcomes after major trauma: women are at higher risk of adverse outcomes than men. J Trauma 53: 882-888.

Kritzer MF (2002). Regional, laminar, and cellular distribution of immunoreactivity for ER alpha and ER beta in the cerebral cortex of hormonally intact, adult male and female rats. Cereb Cortex 12: 116-128.

Lebron-Milad K, Milad MR (2012). Sex differences, gonadal hormones and the fear extinction network: implications for anxiety disorders. Biol Mood Anxiety Disord 2: 3.

Levine ES, Kolb JE (2000). Brain-derived neurotrophic factor increases activity of NR2B-containing N-methyl-D-aspartate receptors in excised patches from hippocampal neurons. J Neurosci Res 62: 357-362.

Milad MR, Igoe SA, Lebron-Milad K, Novales JE (2009). Estrous cycle phase and gonadal hormones influence conditioned fear extinction. Neuroscience 164: 887-895.

Milad MR, Zeidan MA, Contero A, Pitman RK, Klibanski A, Rauch SL et al (2010). The influence of gonadal hormones on conditioned fear extinction in healthy humans. Neuroscience 168: 652-658.

Milner TA, Thompson LI, Wang G, Kievits JA, Martin E, Zhou P et al (2010). Distribution of estrogen receptor beta containing cells in the brains of bacterial artificial chromosome transgenic mice. Brain Res 1351: 74-96.

Miranda RC, Sohrabji F, Toran-Allerand D (1994). Interactions of estrogen with the neurotrophins and their receptors during neural development. Hormones Behav 28: 367-375.

Ninan I (2014). Synaptic regulation of affective behaviors; role of BDNF. Neuropharmacology 76 Pt C: 684-695.

Oyola MG, Portillo W, Reyna A, Foradori CD, Kudwa A, Hinds L et al (2012). Anxiolytic effects and neuroanatomical targets of estrogen receptor-beta (ERbeta) activation by a selective ERbeta agonist in female mice. Endocrinology 153: 837-846.

Pare D, Quirk GJ, Ledoux JE (2004). New vistas on amygdala networks in conditioned fear. J Neurophysiol 92: 1-9.

Parker WH, Jacoby V, Shoupe D, Rocca W (2009). Effect of bilateral oophorectomy on women's long-term health. Womens Health (Lond Engl) 5: 565-576.

Pattwell SS, Bath KG, Perez-Castro R, Lee FS, Chao MV, Ninan I (2012a). The BDNF Val66Met polymorphism impairs synaptic transmission and plasticity in the infralimbic medial prefrontal cortex. J Neurosci 32: 2410-2421.

Pattwell SS, Duhoux S, Hartley CA, Johnson DC, Jing D, Elliott MD et al (2012b). Altered fear learning across development in both mouse and human. Proc Natl Acad Sci USA 109: 16318-16323.

Quirk GJ, Russo GK, Barron JL, Lebron K (2000). The role of ventromedial prefrontal cortex in the recovery of extinguished fear. J Neurosci 20: 6225-6231.

Rey CD, Lipps J, Shansky RM (2013). Dopamine D1 receptor activation rescues extinction impairments in low-estrogen female rats and induces cortical layer-specific activation changes in prefrontal-amygdala circuits. Neuropsychopharmacology 39: $1282-1289$.

Schmidt PJ, Rubinow DR (2009). Sex hormones and mood in the perimenopause. Ann N Y Acad Sci 1179: 70-85.

Schnatz PF, Whitehurst SK, O'Sullivan DM (2010). Sexual dysfunction, depression, and anxiety among patients of an inner-city menopause clinic. J Womens Health (Larchmt) 19: 1843-1849.

Sepulveda-Orengo MT, Lopez AV, Soler-Cedeno O, Porter JT (2013). Fear Extinction Induces mGluR5-Mediated Synaptic and Intrinsic Plasticity in Infralimbic Neurons. J Neurosci 33: 7184-7193. 
Shughrue PJ, Lane MV, Merchenthaler I (1997). Comparative distribution of estrogen receptor-alpha and -beta mRNA in the rat central nervous system. J Comp Neurol 388: 507-525.

Singh M, Meyer EM, Simpkins JW (1995). The effect of ovariectomy and estradiol replacement on brain-derived neurotrophic factor messenger ribonucleic acid expression in cortical and hippocampal brain regions of female Sprague-Dawley rats. Endocrinology 136: 2320-2324.

Smith CC, McMahon LL (2006). Estradiol-induced increase in the magnitude of long-term potentiation is prevented by blocking NR2B-containing receptors. J Neurosci 26: 8517-8522.

Snyder MA, Cooke BM, Woolley CS (2011). Estradiol potentiation of NR2B-dependent EPSCs is not due to changes in NR2B protein expression or phosphorylation. Hippocampus 21: 398-408.

Spencer JL, Waters EM, Milner TA, Lee FS, McEwen BS (2010). BDNF variant Val66Met interacts with estrous cycle in the control of hippocampal function. Proc Natl Acad Sci USA 107: $4395-4400$.

Strom JO, Theodorsson A, Ingberg E, Isaksson IM, Theodorsson E (2012). Ovariectomy and 17beta-estradiol replacement in rats and mice: a visual demonstration. J Vis Exp 64: e4013.
Walf AA, Koonce CJ, Frye CA (2008). Estradiol or diarylpropionitrile decrease anxiety-like behavior of wildtype, but not estrogen receptor beta knockout, mice. Behav Neurosci 122: 974-981.

Wang H, Stradtman GG 3rd, Wang XJ, Gao WJ (2008). A specialized NMDA receptor function in layer 5 recurrent microcircuitry of the adult rat prefrontal cortex. Proc Natl Acad Sci USA 105: 16791-16796.

Wei J, Yuen EY, Liu W, Li X, Zhong P, Karatsoreos IN et al (2013). Estrogen protects against the detrimental effects of repeated stress on glutamatergic transmission and cognition. Mol Psychiatry (in press).

Williams K (1993). Ifenprodil discriminates subtypes of the $\mathrm{N}$-methyl-D-aspartate receptor: selectivity and mechanisms at recombinant heteromeric receptors. Mol Pharmacol 44: 851-859.

Xiao X, Yang Y, Zhang Y, Zhang XM, Zhao ZQ, Zhang YQ (2013). Estrogen in the anterior cingulate cortex contributes to painrelated aversion. Cereb Cortex 23: 2190-2203.

Zeidan MA, Igoe SA, Linnman C, Vitalo A, Levine JB, Klibanski A et al (2011). Estradiol modulates medial prefrontal cortex and amygdala activity during fear extinction in women and female rats. Biol Psychiatry 70: 920-927.

Zucker RS (1989). Short-term synaptic plasticity. Annu Rev Neurosci 12: 13-31. 